\title{
Effect of spiritual intelligence on spiritual health during the COVID-19 pandemic
}

\begin{tabular}{|c|c|}
\hline \multicolumn{2}{|l|}{$\begin{array}{l}\text { Authors: } \\
\text { Badrudin }^{1,2} \\
\text { Aan Komariah }^{3,} \\
\text { Candra Wijaya } \\
\text { Barowi }^{7,8} \\
\text { Akib }^{9,10} \\
\text { Samrin }^{11,12,13}\end{array}$} \\
\hline \multicolumn{2}{|c|}{$\begin{array}{l}\text { Affiliations: } \\
{ }^{1} \text { Department of Islamic } \\
\text { Educational Management, } \\
\text { Faculty of Tarbiyah and } \\
\text { Teacher Training, Universitas } \\
\text { Islam Negeri Sunan Gunung } \\
\text { Djati, Bandung, Indonesia }\end{array}$} \\
\hline $\begin{array}{l}{ }^{2} \text { Department } \\
\text { Educational } \mathrm{M} \\
\text { Program of Po } \\
\text { Institut Agam } \\
\text { Cipasung, Tasi } \\
\text { Indonesia }\end{array}$ & $\begin{array}{l}\text { f Islamic } \\
\text { inagement, } \\
\text { tgraduate, } \\
\text { Islam } \\
\text { malaya, }\end{array}$ \\
\hline \multicolumn{2}{|c|}{$\begin{array}{l}{ }^{3} \text { Department of Educati } \\
\text { Administration, Faculty } \\
\text { Science Education, } \\
\text { Universitas Pendidikan } \\
\text { Indonesia, Bandung, } \\
\text { Indonesia }\end{array}$} \\
\hline $\begin{array}{l}{ }^{4} \text { Department } \\
\text { School of Post } \\
\text { Studies, Unive } \\
\text { Pendidikan Ga } \\
\text { Indonesia }\end{array}$ & $\begin{array}{l}\text { f Leadership, } \\
\text { raduate } \\
\text { sitas } \\
\text { nesha, Bali, }\end{array}$ \\
\hline \multicolumn{2}{|c|}{$\begin{array}{l}{ }^{5} \text { Postgraduate Program of } \\
\text { Islamic Education } \\
\text { Management, Faculty of } \\
\text { Tarbiyah and Teacher } \\
\text { Training, State Islamic } \\
\text { University of North Sumatra, } \\
\text { Medan, Indonesia }\end{array}$} \\
\hline $\begin{array}{l}\text { 6Faculty of Isla } \\
\text { Dharmawangs } \\
\text { Medan, Indon }\end{array}$ & $\begin{array}{l}\text { nic Educatio } \\
\text { University, } \\
\text { sia }\end{array}$ \\
\hline \multicolumn{2}{|c|}{$\begin{array}{l}\text { 7Department of Islamic } \\
\text { Educational Management, } \\
\text { Faculty of Tarbiyah and } \\
\text { Teacher Training, Universitas } \\
\text { Islam Nahdlatul Ulama } \\
\text { Jepara, Jepara, Indonesia }\end{array}$} \\
\hline Read online & \\
\hline 回触回: & $\begin{array}{l}\text { Scan this } Q R \\
\text { code with your } \\
\text { smart phone or } \\
\text { mobile device } \\
\text { to read online. }\end{array}$ \\
\hline
\end{tabular}

According to the Islamic thoughts, conditions for spirituality have been proposed to be theism, prophecy, resurrection, piety, knowledge and so forth. However, non-religious spiritual schools have various shortcomings, the most important of which are temporary, devoid of truth, contradictions and one-dimensionality. Hence, the present study investigated the relationship between spiritual intelligence and spiritual health of Muslim medical students of Penang, Kuala Lumpur and in Malaysia during the COVID-19 pandemic. Hence, 1000 medical students were selected as the statistical population by simple sampling method and standard questionnaires were used to collect data. Data analysis confirmed a positive and significant relationship between spiritual intelligence and spiritual health amongst medical students $(r=0.78, p=0.00)$ by Statistical Package for the Social Sciences (SPSS) software. Moreover, results indicated the benefit of Islamic teachings with the spirituality required by human beings. Modern human life, with its significant advances in the material areas, has not been successful in paying attention to spirituality and thus neglected it. Therefore, various mental diseases are caused by material domination in the lives of today's people that are devoid of spirituality. Furthermore, the emergence of various secular spiritual schools verifies that Western societies, in particular, after the failure of the church, are one of the reasons for the emergence of such false spiritualties. With regard to the unity of spirituality and religion, therefore, spirituality cannot be separated from religion in different ways.

Contribution: This article contributes to the relationship between spiritual intelligence and spiritual health of Muslim medical students.

Keywords: religion; spirituality; spiritual intelligence; spiritual health; Malaysia.

\section{Introduction}

People with adequate spiritual health are strong people who have more social support and control, are more capable of adapting to spiritual stress and take the necessary measures to adapt and deal with problems and crises incurred (Pant \& Sirvastava 2017:87). The spiritual health of healthcare providers, especially physicians and nurses, plays a crucial role in the provision of holistic care. Meanwhile, students whose aim is to provide patient care in the future should have favourable spiritual health (Lambert et al. 2007). The spiritual beliefs formed during student life have a significant impact on students' spiritual attitudes towards patients' spiritual affairs. The higher the spiritual health of students, the better their ability to provide spiritual care in the future, which is a part of holistic care (Kalkim, Midilli \& Daghan 2018:286). Evidence has been indicative of the important role of spiritual intelligence in the enhancement of spiritual health. In fact, students with high spiritual intelligence will have a proper understanding of various aspects of health, including spiritual health and the use of this intelligence in clinical settings can play an important role in patient health promotion (Cilliers \& Terblanche 2014:279).

\footnotetext{
${ }^{8}$ Program Sufism Islamic Studies, Walisongo State Islamic University, Semarang, Indonesia

${ }^{9}$ Department of Islamic Educational Management, Postgraduate Program, State Islamic Institute of Kendari, Kendari, Indonesia

${ }^{10}$ Department of Elementary Teacher Education, Faculty of Teacher Training, Universitas Terbuka UPPJ Kendari, Indonesia

${ }^{11}$ Department of Islamic Educational Management, Faculty of Tarbiyah and Teacher Training, State Islamic Institute of Kendari, Kendari, Indonesia

${ }^{12}$ Department of Islamic Education Religion, Faculty of Teacher Training, Muhammadiyah University of Kendari, Sulawesi Tenggara, Indonesia

${ }^{13}$ Dean's Office, Faculty of Theology and Religion, University of Pretoria, Pretoria, South Africa

Corresponding author: Aan Komariah, aan_komariah@upi.edu

Dates: Received: 06 Mar. 2021|Accepted: 05 July 2021|Published: 11 Nov. 2021

How to cite this article: Badrudin., Komariah, A., Wijaya, C., Barowi., Akib. \& Samrin., 2021, 'Effect of spiritual intelligence on spiritual health during the COVID-19 pandemic', HTS Teologiese Studies/Theological Studies 77(1), a6594. https://doi.org/10.4102/hts. v77i1.6594

Copyright: ( ) 2021. The Authors. Licensee: AOSIS. This work is licensed under the Creative Commons Attribution License.

Note: Special Collection: Faith Seeking Understanding, sub-edited by Seyed Mehdi Mousavi (Payame Noor University, Tehran, Iran) and
} the Dean's Office of the Faculty of Theology and Religion of the University of Pretoria. 
Spiritual health is about the connection with self, others, nature and God (transcendental dimension), which can be obtained through a dynamic and cohesive growth process and can lead to the recognition of the ultimate purpose and the meaning of life. As humans operate as an integrated system, these two dimensions overlap and interact with one another despite being independent, thereby creating a sense of spiritual health, which results in satisfaction and purposefulness in life (Mahasneh et al. 2015). On the one hand, people who consider themselves spiritual are better able to cope with stress and take the necessary measures to deal with life crises. On the other hand, people may get depressed, feel isolated and lose the meaning of life when their spiritual health is at risk (Akrawi et al. 2017). Spiritual health can play a considerable role in enhancing spiritual growth because it is related to people's beliefs (Kaur, Sambasivan \& Kumar 2013). Spiritual health is defined as a set of capabilities related to spiritual resources, which involves an effective form of adaptation and problemsolving behaviour. Spiritual intelligence goes beyond people's physical and cognitive relations with the surrounding environment and enters the intuitive and transcendent realm of one's view of life, thereby causing the person to deal with their daily stress in life and even help others by discovering hidden life resources (Qiu et al. 2020; Yang 2006; Zhu et al. 2020).

Workplace spirituality is a new concept that has emerged in the management and business literature in the past few years and has been used as a novel paradigm, the guidance and management of which in the organisation is one of the most important future activities of organisational managers. In fact, spirituality seems to have a correlation with other organisational variables (Hsiao, Chiang \& Chien 2010:386). Researchers have mentioned different variables in this area and institutionalisation of workplace spirituality can provide organisational health (Pesut 2002:128). In addition, the optimal health status of people in the community is the most important factor for progress and survival and a community will not last without maintaining and ensuring the health of people. The concept of spirituality is related to all health areas at all ages. Spiritual health is the only force that makes up the physical, mental and social dimensions of man and is determined by characteristics of stability in life, peace, balance and harmony, a sense of closeness to oneself, God, society and the environment. In fact, spiritual health is one of the dimensions of health that leads to the integration of other dimensions (Baloochi, Abazari \& Mirzae 2018:2). Workplace spirituality can be a positive strong force in people's life because people create more enjoyable, balanced and meaningful work and cultivate their soul and spirit by integrating their work and spiritual life (Jiang et al. 2020:112). In a spiritual environment, people consider their work as a way for creativity, self-expression and learning and money comes as a second reward. In addition, changes in the world are a normal issue to these people and they do not resist organisational changes. These people are eager to serve others and consider the development of their abilities to be dependent on serving others. The mentioned points can guarantee organisational effectiveness and survival and can increase organisational health.

Spiritual health and intelligence are closely related to organisational health. In fact, workplace spirituality can integrate the achievement of goals. Throughout history, people have had different perceptions of spirituality, which has been defined based on a dimension of the concept (Yang \& Moa 2007:999). Over the past few decades, attention to spirituality in organisations and their benefits for human beings, groups and organisations have had an increasing trend and can be considered as an emerging construct in a broader context of workplace spirituality. Organisational spirituality is defined as a framework of organisational values embedded in culture, which promotes the experience of excellence and a sense of connection with others through work processes in a way that leads to perfection and satisfaction (Elkins \& Cavendish 2004:179). Employees who have a deep sense of meaning in their work believe that people are connected to each other, feel solidarity with others in the workplace and their values and goals are in line with organisational values. Some experts define the term 'spirituality' as employees' experience of working with high energy, being satisfied with and having meaning and goals in work and establishing an effective relationship with other employees (Emmons 2000:3).

Spiritual intelligence refers to individual aspects, whereas workplace spirituality is related to organisational aspects of the concept. According to some researchers, spirituality is recognising an aspect of employees' life, which is internal, intrinsic and nurturing and is developed by doing meaningful works in life. In addition, spiritual intelligence can help people expand their realm of consciousness and improve their productivity (Pesut \& Reimer-Kirkham 2010). People turn to God in hardship and ask for his help. This is observed in the nature of all people in the world. God Almighty has referred to this issue in various surah of the Quran. He states 'when they board the ship, they invoke Allah putting exclusive faith in Him' (Surah Al-Ankabut-56), or 'when distress befalls people, they supplicate their Lord' (Surah ArRoom-33), or 'when distress befalls man, he supplicates us' (Az-Zumar-94). Humans' attention to God is an intrinsic matter and is not limited to a specific time and space. However, some people may go stray or be fooled. Nevertheless, humankind turns to God intrinsically, and this act is beyond time and space. Considering the mentioned points, not only does COVID-19 have a positive effect on religious beliefs but it also deepens them. Its witness is more attention of people to spirituality worldwide. Nonetheless, this intrinsic need of humanity to spirituality has increased with the outbreak of COVID-19. However, despite the problems incurred because of the virus, more attention to spirituality is the positive aspect of the disease. Considering the importance of the issue, the present study aimed to evaluate the role of spiritual intelligence on spiritual health amongst Muslim students of Malaysia during the COVID-19 pandemic. 
H1: There is a positive relationship between spiritual intelligence and spiritual health amongst nursing and medical students of Malaysia in 2020.

\section{Methodology}

The present research aimed to evaluate the relationship between spiritual intelligence and spiritual health of 10000 nursing and medical students of Penang, Kuala Lumpur, and Malaysia in 2020 using SPSS software. It is noteworthy that the research was carried out by testing a hypothesis. Firstly, the researcher developed the research design and collected the related literature, presenting the research hypothesis following the assessment of theoretical foundations. Data were collected using a library method and field data. In addition, the theoretical foundation of the research, thematic literature, history of the issue and research topic was evaluated by applying library methods, studying dissertations and related research and using online databases. In addition, the field method was exploited to implement the main research stages and collect data. The statistical population included 1000 medical and nursing students in Penang, Kuala Lumpur, in 2020, who were selected by simple random sampling method. Spiritual intelligence was assessed using the 15-item spiritual intelligence self-report inventory by King (2008). In addition, the spiritual well-being scale (SWBS) by Paloutzian and Ellison (1982) was applied to assess spiritual health.

Overall, 924 questionnaires were completed properly, according to which the statistical analysis was carried out, and the incomplete tools were eliminated. In all, 521 subjects were male and the rest were female $(n=403)$. In terms of marital status, $38 \%$ of the participants were married and $62 \%$ were single. In addition, $56 \%$ of the subjects were medical students and the rest were nursing students working in a hospital. Moreover, $31 \%$ of the individuals were first-year students whilst $33 \%, 26 \%$ and $10 \%$ of them were second, third and last-year students, respectively.

\section{Results}

The reliability of the tools was measured by performing a pretest (distributing 30 questionnaires amongst samples), and the confidence coefficient was measured in SPSS. According to the results, Cronbach's alphas of 0.78, 0.80 and 0.84 were obtained for 15 items of spiritual intelligence, 20 items of spiritual health and the entire questionnaire, respectively. It is noteworthy that the values above 0.70 showed proper reliability of the questionnaire. The validity of the questionnaire was confirmed by managers of several hospitals and specialised professors in the field. In addition, the z-test was used to assess the status of each of the research variables. Notably, the mean community was assessed at a 0.05 error rate. Table 1 shows the results of the z-test in the statistical population.

Moreover, Table 2 illustrates the results of analysing the hypothesis based on $r$ and $p$ statistics in SPSS software.
TABLE 1: Z-test results of research variables.

\begin{tabular}{lccccc}
\hline Variable & $\boldsymbol{N}$ & Mean & SD & $\boldsymbol{T}$ & $\boldsymbol{p}$ \\
\hline Spiritual intelligence & 924 & 4.178 & 0.3567 & 28.365 & 0.00 \\
Spiritual health & 924 & 4.021 & 0.5142 & 23.146 & 0.00 \\
\hline
\end{tabular}

SD, standard deviation.

TABLE 2: Research hypotheses test results.

\begin{tabular}{llccc}
\hline No. & Hypothesis & $\boldsymbol{r}$ & $\boldsymbol{p}$ & Result \\
\hline 1 & Spiritual intelligence $\rightarrow$ Spiritual health & 0.78 & 0.00 & Positive \\
\hline
\end{tabular}

Based on the values obtained, there was a positive relationship between spiritual intelligence and spiritual health in Malaysian students. As the ' $r$ ' is positive, and the ' $\mathrm{p}$ ' is less than 0.05 , the positive relationship between research variables is confirmed.

\section{Discussion}

One of the most widespread and worst global crises has occurred recently. The contagious and mysterious disease caused by COVID-19 has somehow affected all the people of the world. Meanwhile, those interested in the field of 'spiritual health' have assessed individual and social crisis management whilst being aware of the positive effects of spirituality. As a comprehensive and complete religion, Islam has the best plans for spreading and explaining spirituality and spiritual health in society. Not only attention to various aspects of spirituality and its components contributes to the tranquility and health of Muslims but also a deeper understanding in this area can be a factor for increased religiosity and theism. In addition, Islam is a guide for all humanity in the divine religions. Considering the research topic, the direct relationship between physicians and nurses with COVID-19-positive cases has led to more attention to the role of medicine in the fight against COVID-19 these days. On the other hand, numerous hospitals and healthcare centres are barely able to provide healthcare services to patients because of a shortage of facilities, physicians and nurses. As such, it is worthwhile to address the variables involved in providing medical services in the hospital in critical situations. Therefore, the present study aimed to evaluate the spiritual intelligence and spiritual health of physicians and nurses. According to the results, there was a positive relationship between spiritual intelligence and spiritual health of medical and nursing Malaysian students in $2020(r=0.78, p=0.00)$.

Throughout decades, health has been analysed based on specific dimensions (physical, mental and social health). After a while, researchers introduced spiritual health as another aspect of health concept and an important dimension of individual and group life. Many years ago, the World Health Organization (WHO) was faced with the issue of whether spirituality should be included in the definition of health along with physical, mental and social health or not. Through self-report, the majority of people say that they have a spiritual life. Today, most health models include spiritual health. The concept of spirituality 
is related to all aspects of health at all ages and is taken into account by all researchers in the world. Today, there is a growing trend of spiritual needs at the international level. According to an organisational belief, employees are the most important assets of organisations and many of these centres have focused more on the existential value of man. However, a difference in this area is related to their focus on spiritual dimensions. On the one hand, recent studies have shown that one of the serious problems of managers in organisations (especially hospitals) is work-related stress and consequent reduction of individual and organisational productivity.

In addition to individual damages, job stress includes issues such as hopelessness, a pessimistic view towards a future career, lack of positive motivation, decreased constructive occupational efforts, lack of sympathy, negativity, irritability, a tendency to justify failures and attribute them to others and a lack of professional creativity. This has consequences of high costs for organisations, such as frequent job changes, frequent absenteeism and vacations, a decline in the quantity and quality of work and mental health disorders. Today is the era of competition and complexity and all organisations constantly deal with one another and mostly have predictable behaviours. Therefore, encouraging people to develop their spirituality and laying the ground for this issue by the leaders or managers of the organisation is of paramount importance. This leads to an increased inner motivation for employees to work harder.

\section{Conclusion}

Given the research conducted on the relationship between spirituality and numerous variables, growing organisations and institutions have focused more on the enhancement of spirituality and capabilities, improvement of creativity and increase of occupational satisfaction and decrease of employees' job stress to optimise human resources and increase work function in these individuals. In this regard, researchers have shown that emphasis on spiritual intelligence and its dimensions in an organisation will lead to the preparation of an environment that improves psychological health in employees whilst decreasing their job stress. Therefore, managers and leaders seek to reconnect employees with their nature and encourage them to turn to spiritual or meaningful affairs. This has led to the formation of a concept known as workplace spirituality. Therefore, workplace spirituality can be used as the only therapeutic drug for hospital contingency management during the COVID-19 outbreak. In addition to improving spiritual health, physicians and nurses enhance the spiritual environment of organisations with the help of spirituality and can deal with challenges caused by COVID-19 more appropriately. Given the inevitability of some stressors in different professions and the necessity of preventing psychological and behavioural effects of stress, it is recommended that proper measures be taken by managers of organisations, especially in stressful environments such as hospitals during the COVID-19 outbreak, to improve the working conditions of nurses and physicians and increase the benefits of this issue for patients.

\section{Acknowledgements Competing interests}

The authors declare that they have no financial or personal relationships that may have inappropriately influenced them in writing this article.

\section{Authors' contributions}

All authors contributed in the writing of the article.

\section{Ethical considerations}

To adhere to ethical considerations, the research objectives were explained to the subjects and they were ensured of the confidentiality terms regarding their personal information. In addition, informed consent was obtained prior to the research.

\section{Funding information}

This research received no specific grant from any funding agency in the public, commercial or not-for-profit sectors.

\section{Data availability}

Data are available upon request from the corresponding author.

\section{Disclaimer}

The views and opinions expressed in this article are those of the authors and do not necessarily reflect the official policy or position of any affiliated agency of the authors.

\section{References}

Akrawi, D., Bartrop, R., Surgenor, L., Shanmugam, S., Potter, U. \& Touyz, S., 2017, 'The relationship between spiritual, religious and personal beliefs and disordered
eating psychopathology', Translational Developmental Psychiatry 5(1), 44-55. eating psychopathology', Translational Developm
https://doi.org/10.1080/20017022.2017.1305719

Baloochi, A., Abazari, F. \& Mirzae, M., 2018, 'The relationship between spiritual intelligence and aggression in medical science students in the southeast of Iran', International Journal of Adolescent Medicine and Health 4(2), 2-7.

Cilliers, F. \& Terblanche, L., 2014, 'The role of spirituality in coping with the demands of the hospital culture amongst fourth-year nursing students', International Review of Psychiatry 26(3), 279-288. https://doi.org/10.3109/09540261.2014.89 0922

Elkins, M. \& Cavendish, R., 2004, 'Developing a plan for pediatric spiritual care', Holistic Nursing Practice 18(4), 179-184. https://doi.org/10.1097/00004650200407000-00002

Emmons, R.A., 2000, 'Is spirituality an intelligence? Motivation, cognition, and the psychology of ultimate concern', The International Journal for the Psychology of Religion 10(1), 3-26. https://doi.org/10.1207/S15327582IJPR1001_2

Hsiao, Y.-C., Chiang, H.-Y. \& Chien, L.-Y., 2010, 'An exploration of the status of spiritual health among nursing students in Taiwan', Nurse Education Today 30(5), 386-392. https://doi.org/10.1016/j.nedt.2009.05.001

Jiang, X., Denga, L., Zhu, Y., Jia, H., Taoc, L., Liua, L. et al., 2020, 'Psychological crisis intervention during the outbreak period of new coronavirus pneumonia from experience in Shanghai', Psychiatry Research 286, 112-116. https://doi. org/10.1016/j.psychres.2020.112903

Kalkim, A., Midilli, T.S. \& Daghan, S., 2018, 'Nursing students' perceptions of spirituality and spiritual care and their spiritual care competencies: A correlational research study', Journal of Hospice \& Palliative Nursing 20(3), 286-295. https://doi. org/10.1097/NJH.0000000000000446 
Kaur, D., Sambasivan, M. \& Kumar, N., 2013, 'Effect of spiritual intelligence, emotional intelligence, psychological ownership and burnout on caring behaviour of nurses:
A cross-sectional study', Journal of Clinical Nursing 22(21-22), 3192-3202. A cross-sectional study', Journal
https://doi.org/10.1111/jocn.12386

King, D., 2008, 'Rethinking claims of spiritual intelligence: A definition, model and measure', Unpublished Master's thesis, Trent University.

Lambert, V.A., Lambert, C.E., Petlini, M., Li, X.M. \& Zhang, Y.J., 2007, 'Workplace and personal factors associated with physical and mental health in hospital nurse china', Nursing and Health Sciences 9(1), 120-126. https://doi.org/10.1111/ j.1442-2018.2007.00316.x

Mahasneh, A.M., Shammout, N.A., Alkhazaleh, Z.M., Al-Alwan, A.F. \& Abu-Eita, J.D., 2015, 'The relationship between spiritual intelligence and personality traits among Jordanian university students', Psychology Research and Behavio Management 8, 89-97. https://doi.org/10.2147/PRBM.S76352

Paloutzian, R. \& Ellison, C., 1982, 'Loneliness, spiritual well-being and the quality of life', in D. Peplau \& D. Perlman (eds.), Loneliness: A sourcebook of current theory, research and therapy, p. 124, John Wiley and Sons, New York, NY.

Pant, N. \& Srivastava, S., 2017, 'The impact of spiritual intelligence, gender and educational background on mental health among college students', Journal of Religion and Health 58(1), 87-108. https://doi.org/10.1007/s10943-017-0529-3
Pesut, B., 2002, 'The development of nursing students' spirituality and spiritual caregiving', Nurse Education Today 22(2), 128-135. https://doi.org/10.1054/nedt. 2001.0664

Pesut, B. \& Reimer-Kirkham, S., 2010, 'Situated clinical encounters in the negotiation of religious and spiritual plurality: A critical ethnography', International Journal of Nursing Studies 47(7), 815-825. https://doi.org/10.1016/j.ijnurstu.2009.11.014

Qiu, J., Shen, B., Zhao, M., Wang, Z., Xie, B. \& Xu, Y., 2020, 'A nationwide survey of psychological distress among Chinese people in the COVID-19 epidemic: Implications and policy recommendations', General Psychiatry 33(2), e100213. https://doi.org/10.1136/gpsych-2020-100213

Yang, K.-P., 2006, 'The spiritual intelligence of nurses in Taiwan', The Journal of Nursing Research 14(1), 24-35. https://doi.org/10.1097/01.JNR.0000387559. 26694.0b

Yang, K.P. \& Moa, X.Y., 2007, 'A study of nurse's spiritual intelligence: Across-sectional questionnaire survey', International Journal of Nursing Studies 44(6), 999-1010. https://doi.org/10.1016/j.ijnurstu.2006.03.004

Zhu, Y., Chen, L., Ji, H., Xi, M., Fang, Y. \& Li, Y., 2020, 'The risk and prevention of novel coronavirus pneumonia infections among inpatients in psychiatric hospitals', Neuroscience Bulletin 36, 299-302. https://doi.org/10.1007/s12264-020 00476-9 